\title{
SENI SEBAGAI MEDIA DAKWAH PADA ANAK USIA DINI
}

\section{Nur Rahmayani}

\section{Fatmawati Fatmawati}

\section{Mohammad Nur Ahsan}

\author{
Institut Agama Islam Negeri Palu
}

Email:runnasha@gmail.com

\section{Abstract:}

This paper deals with the art as media of preaching in early childhood at the Early Childhood Education Institution of Kabelo Singgah-Singgani, Palu. The questions include (1) How does art become media of preaching in early childhood at this institution? (2) How is the implementation of art as media of preaching in early childhood at this institution? The result showed that, first, the art which is categorized as media of preaching is one which contains Islamic values. This Islamic art which is taught in this educational institution includes dances such as Kaili's local dance called momonte, qasidah songs, Arabic calligraphy that contains Quranic verses, Hadith, and Islamic poetry. Various art instruments provided by this institution in supporting children's activities comprise guitar, rebana (tambourine), kerincing (triangle), and sound system. The benefits of art gained by the children include giving joyful entertainment to children, introducing Islam through art, and habituating them with Islamic and local cultures. In addition, art will become a way to sharpen instinct and teach Islam with the tenderness of art.

$$
\begin{aligned}
& \text { تناول هذا البحث في الفن كوسيلة الدعوة في مرحلة الطفولة المبكرة في المدرسة في مرحلة الطفولة }
\end{aligned}
$$

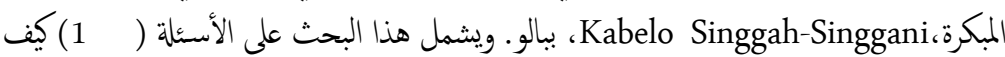

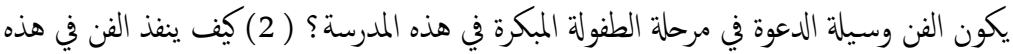

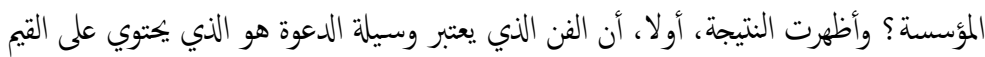

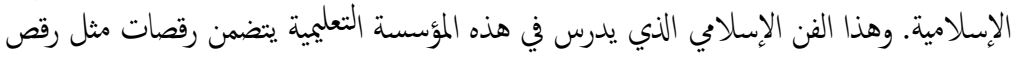

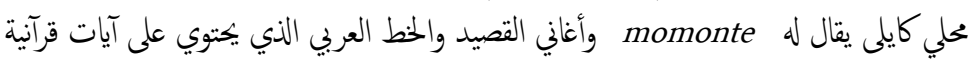

$$
\begin{aligned}
& \text { ومتون الحديث والشعر الإسلامي. و كانت الأدوات الفنية المختلفة التي تقدها هذه المؤسسة في دئ الماتي }
\end{aligned}
$$


Nur Rahmayani, Fatmawati \& Mohammad Nur Ahsan, Seni Sebagai...

$$
\begin{aligned}
& \text { أنشطة الأطفال تشتمل على الغيتار والدف والمثلث ونظام الصوت. وكانت فوائد الفن التي اكتسبه }
\end{aligned}
$$

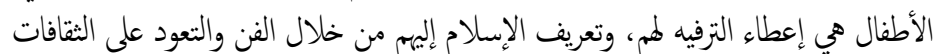

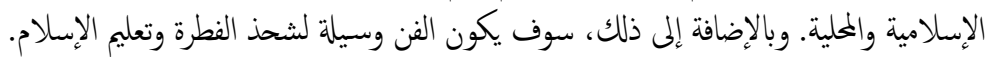

Kata Kunci : seni, media, dakwah, anak usia dini.

\section{A. Pendahuluan}

Dakwah selama ini masih dipahami secara keliru dan sempit, hanya berfokus pada ceramahdan khutbah yang cenderung hanya mengedepankan retorika belaka. Kondisi ini mengakibatkan bahwa kurang mendapatkan apresiasi, baik dalam tataran praktis di lapangan maupu nkajian teoritis di dunia akademik. Lebih dari itu, kesalahpahaman dan kekeliruan memahami makna dakwah tentu saja akan mengakibatkan kesalahan langkah dalam operasional dakwah sehingga dakwah yang dilakukan menjadi tidak simpatik dan tidak membawa perubahan apa-apa. ${ }^{1}$

Banyak hal dari kegiatan dakwah yang dilakukan di lembaga pendidikan PAUD, seringkali dirasa mengenai kepada sasaran dakwahnya sangat tepat dengan ruang lingkup yang dialami pendidik di lembaga pendidikan anak usia dini. Dari mulai berdakwah dalam lembaga pendidikan sendiri sampai di luar pendidikan, semuany amenggunakan model dan cara dakwah masing-masing. Setidaknya ada perubahan dan peningkatan menuju kebaikan mad'u yang diharapkan dari setiap lembaga dakwah sebagaimana yang diharapkan lembaga Pendidikan Anak Usia Dini (PAUD).

${ }^{1}$ Said bin Ali Al-Qahthani, Dakwah Islam DakwahBijak, (Jakarta: GemaInsani Press, 1994), h. 14. 


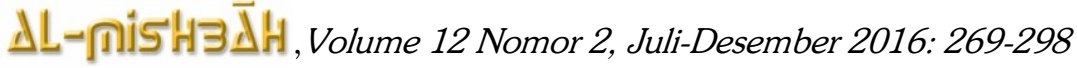

Fenomena yang menarik sampai saat ini masih bisa dinikmati sehari-hari yaitu, merebaknya aktivitas dakwah. Aktivitas dakwah kini hanya dijumpai di tempat-tempat seperti: masiid, pesantren, dan majlis taklim, tetapi dapat pula dijumpai di rumah sakit, perusahaan, hotel, radio, televisi bahkan internet. ${ }^{2}$ Meskipun banyak fenomena dakwah, namun tindakan kekerasan, kerusuhan sosial, pornoaksi, pornografi, korupsi, semakin juga merajalela. Artinya, fenomena tersebut mengindikasikan masih terealisasinya dakwah dari realitas sosial masyarakat di sekitarnya.

Menurut Toto Tasmara;

"Bahwa aktivitas dakwah sebagai proses komunikasi penyampaian materi ajaran ideal Islam, selama ini dirasa belum mempunyai kepoweran untuk membawa masyarakat kepada perubahan yang lebih baik. Ada banyak faktor yang menjadi penyebabnya, salah satunya adalah karena dakwah yang selama ini dilakukan cenderung kering, impersonal, dan hanya bersifat informatif belaka, belum menggunakan teknik-teknik komunikasi yang efektif." ${ }^{3}$

Situasi ini merupakan cermin wajah dakwah yang belum berpijak di atas realitas sosial yang ada. Padahal dakwah dan realitas sosial memilik ihubungan interpedensi yang sangat kuat. ${ }^{4}$ Beberapa hal penting yang perlu diketahui dalam dakwah adalah, bahwa ada dua segi dakwah yang tidak dapa dipisahkan, tetapi dapat dibedakan, yaitu menyangkut isi dan bentuk, subtansi dan forma, pesan dan cara penyampaiannya, esensi

${ }^{2}$ Asep Muhyidin dan Agus Ahmad Safei, Metode Pengembangan Dakwah, (Bandung: Pustaka Setia, 2002), h. 12.

${ }^{3}$ Toto Tasmara, Komunikasi Dakwah, (Jakarta: PT. Gaya Media Pratama, 1997), h. 15 .

4Yunan Yusuf, Metode Dakwah Sebuah Pengantar Kajian, (Jakarta: Prenada Media, 2003), 16 
Nur Rahmayani, Fatmawati \& Mohammad Nur Ahsan, Seni Sebagai...

dan metode. Proses dakwah menyangkut kedua-duanya sekaligus dan tidak terpisahkan. Hanya saja, perlu disadari bahwa isi, pesan dan esensi senantiasa mempunyai dimensi universal yang tidak terkait oleh ruang dan waktu.Dalam hal ini subtansi dakwah adalah pesan keagamaan itu sendiri, Itulah sisi pertama dalam dakwah. Sisi kedua, meski pun tidak kurang pentingnya dalam dakwah, yakni sisi bentuk, formal, cara penyampaian dan metode. ${ }^{5}$

Selain hal di atas, sebuah media dakwah juga penting untuk di mengerti di dalam proses komunikasi dakwah. Berbicara media dakwah, tentunya tidak lepas dari metode yang di lakukan dalam melakukan dakwah. Pengembangan metode dakwah sangat terkait dengan media yang harus menyertainya. Seorang dai, misalkan harus mampu memilih media dakwah yang relevan dengan kondisi mad'u (yang didakwahi) yang telah dipelajari secara komprehensif dan berkesinambungan. Kegiatan dakwah yang dilakukan dengan mempertimbangkan kondisi audiens tersebutakan lebih memberikan hasil yang jelas.

Tentu saja seorang dai hendaklah memilih metode dan media yang dari masa kemasa terus berkembang, sepertimimbar, panggung, media cetak, atau elektronik (radio, internet, televisi dan computer). Kemudian dengan mengembangkan media atau metode kultural dan struktural, yakni pranata sosial, seni, karya budaya, dan wisata alam. Juga dengan mengembangkan dan mengakomodasikan metode dan media seni budaya masyarakat setempat yang relevan, seperti wayang, drama, musik, lukisan, dan sebagainya.

\footnotetext{
${ }^{5}$ Ahmad Anas, Paradigma Dakwah Kontemporer, (Semarang: Wali Songo Press IAIN Walisongo, 2006), h. 14-16.
} 


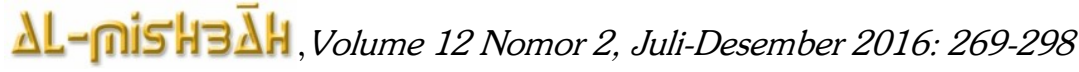

Lembaga pendidikan anak usia dini (PAUD) sebagai bagian dari wadah pengembangan kreatifitas di bidang seni dan budaya, diyakini memiliki andil yang besar dalam melestarikan budaya dakwah islami di Indonesia. Setidaknya ada konsep, cara dan sistem bagaimana lembaga pendidikan anak usia dini (PAUD) mengkomunikasikan dakwahnya melalui seni budaya.

Mengingat komunikasi merupakan proses pemindahan pesan, maka secara esensial bahasa merupaka faktor utama yang harus ada dalam berkomunikasi. Proses komunikasi tersebut, dapat dilakukan melalui bahasa verbal maupun nonverbal termasuk music atau secara bersamaan, sebab sering ketika komunikator menyampaikan pesan pada komunikan melalui bahasa verbal, ternyata sebagian besar komunikan sebenarnya lebih terpengaruh oleh penampilan nonverbal.

Setiap proses dakwah, tentunya memiliki cara atau sistem khusus bagaimana sebuah dakwah bisa tersampaikan. Ada objek sasaran dakwah, ada pula subye kpendakwah. Akan tetapi, sebuah proses dakwah tentu saja tidak akan bisa melepaskan dari konteks kultur ruang lingkup yang dimilikinya. Siapapun atau lembaga apapun ketika memberikan sebuah dakwah, diasumsikan tidak bisa melepaskan diri dari konteks backround darimana dia berasal. Sehingga dapat digambarkan seni dan dakwah lebih menempatkan Islamiah sebagai dua hal yang tak terpisahkan, hadir secara utuh, bahkan salah satu menjembatani yang lain.

Berdasarkan fenomena tersebut, maka dalam proposal skripsi ini peneliti tertarik untuk mengambil judul: "Seni Sebagai Media Dakwah Anak Usia Dini di Lembaga Pendidikan Anak Usia Dini (PAUD) Kabelo Singgah-Singgani Kelurahan Buluri Kecamatan Ulujadi Kota Palu". 
Nur Rahmayani, Fatmawati \& Mohammad Nur Ahsan, Seni Sebagai...

\section{B. Seni}

Seni atau Kesenian merupakan salah satu perwujudan kebudayaan. Kesenian juga selalu mempunyai peranan tertentu di dalam masyarakat yang menjadi ajangnya. Demikian pula di Indonesia, kesenian dapat ditinjau dalam konteks kebudayaan maupun kemasyarakatannya. Ditinjau dalam konteks kebudayaan, akan ternyata bahwa berbagai corak ragam kesenian yang ada di Indonesia ini terjadi karena adanya lapisanlapisan kebudayaan yang bertumpuk dari zaman ke zaman. Di samping itu, keanekaragaman corak kesenian di sini juga terjadi karena adanya berbagai lingkungan budaya yang hidup berdampingan dalam satu masa sekarang ini. Ditinjau dalam konteks kemasyarakatan, akan ternyata bahwa jenis-jenis kesenian tertentu mempunyai kelompok-kelompok pendukug tertentu. Demikian pula, kesenian bisa mempunyai fungsifungsi yang berbeda di dalam kelompok-kelompok manusia yang berbeda.

Di tengah perkembangan zaman yang sangat pesat dengan sistem yang canggih tentu banyak kesenian yang berkembang menyesuaikan dengan perkembangan zaman. Sehingga selalu mempunyai daya tarik dan dapat bertahan hingga sekarang ini. Salah satunya seni tari, seni kaligrafi, dan seni musik Islami yang masih bertahan sampai sekarang, bahkan sering mengadakan pertunjukan-pertunjukan dan memenuhi undangan untuk tampil dalam kegiatan hari-hari besar Islam dan hari besar Nasional. Hal ini membuktikan bahwa kesenian tari, kaligrafi, dan musik Islami masih dibutuhkan sehingga masih dipertahankan oleh masyarakat.

Dalam penelitian ini penulis menggunakan pendekatan antropologi budaya. Secara harfiah antropologi berasal dari bahasa Yunani yaitu kata 


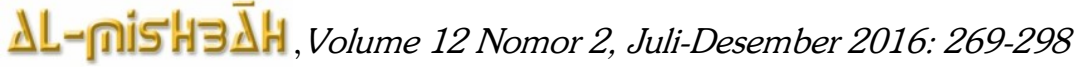

antropos yang berarti manusia dan kata logos yang berarti ilmu atau studi. Pendekatan antropologi budaya adalah suatu pendekatan yang menitik beratkan pada seluruh cara hidup manusia yang mengungkapkan nilainilai yang mendasari perilaku budayanya. Seperti sosial masyarakat, kesenian, sistem kepercayaan, serta seluruh unsur-unsur kebudayaan secara universal. Dengan pendekatan antropologi budaya akan membantu dalam menguraikan tentang seni sebagai media dakwah.

Seni dapat diartikan sebagai segala yang berkaitan dengan karya cipta yang dihasilkan oleh unsur rasa. Sedangkan kesenian dapat diartikan sebagai hasil ekspresi manusia yang mengandung keindahan. Kesenian adalah hasil kemampuan dan kegiatan rasa manusia. Kesenian timbul karena manusia mengagumi keindahan. Keindahan itu kemudian diungkapkan dalam berbagai bentuk kesenian. ${ }^{6}$

Seni berasal dari kata sani yang artinya jiwa yang luhur atau ketulusan hati. Seni dapat pula dikatakan sebagai sebuah arti barang atau karya sebuah kegiatan. Seni merupakan karya yang berasal dari peniruan bentuk alam dengan segala segi-seginya atau mendekati bentuk alam natural.

Dari beberapa pengertian di atas maka dapat disimpulkan bahwa seni yaitu curahan yang tulus, dan jujur manusia yang diwujudkan melalui karya kreatifitas dengan mengedepankan faktor estetis dan psikologis sebagai media interaksi kultural dalam bermasyarakat.

${ }^{6}$ A.A Yudhianta, dkk, Sejarah Budaya Program Pengetahuan Budaya, (Klaten: PT Intan Pariwara, 1988), h. 4. 
Nur Rahmayani, Fatmawati \& Mohammad Nur Ahsan, Seni Sebagai...

1. Karakteristik Seni Islami

Seni Islam mempunyai noktah dan tujuan yang jelas yaitu, sebagai manifestasi beribadah kepada Allah swt. Menurut Islam, seni tidak boleh diklasifikasikan kepada subjek atau objek semata. Ia harus dilihat sebagaimana Islam sendiri memandang sesuatu. Seni tidak boleh dilihat pada satu sudut tertentu tetapi pada sesuatu yang menyeluruh. Sesuai dengan kehidupan yang telah ditentukan oleh Allah swt.

Cara partikal atau amalinya pula melalui teladan kehidupan Rasullulah saw. Oleh sebab itu, Islam mempunyai noktah dan tujuan yang jelas yaitu sebagai manifestasi beribadah kepada Allah swt. Manakala kandungannya seiring dengan nilai-nilai Islam.

Seni Islam mempunyai dasar yang jelas dalam melahirkan proses kreatif di dalam berkarya. Karya seni Islam senantiasa memberikan arah tujuan kehidupan manusia yang lurus sesuai dengan fitrah manusia yang berlandaskan pengabdian, karena Islam mengenal adanya akhirat setelah dunia.

Berdasarkan tujuan dan kandungan seni Islam, maka setiap seniman muslim mestilah memahami nilai seni Islam terdahulu sebelum menguasai sesuatu tentang seni. artinya, nilai Islamlah yang akan menjadi rujukan keseniannya. Seorang seniman yang melahirkan karya seni, tidak terlepas dari pengalaman dan kehidupan yang dijalaninya. Oleh karena itu, jika ia menjalani nilai Islam secara baik dan menyeluruh, maka karya seni yang dihasilkan pasti memancarkan roh ke Islamannya.

\section{Seni Pertunjukkan Islam}

Seni pertunjukan Islam banyak merujuk pada apa yang ada atau terkandung dalam sebuah pagelaran atau pertunjukkan dalam nuansa Islam, artinya setiap unsur yang dibawakan dalam pagelaran atau 
pertunjukkan mempunyai nilai-nilai Islam. Islam sendiri adalah sebuah agama yang menurut persebarannya di Indonesia tergolong yang tercepat, karena dibawakan dan disebarkan dengan cara-cara yang mudah beradaptasi. Edi Sedyawati menjelaskan: "Bahwa seni pertunjukan pada pokoknya adalah sesuatu yang membutuhkan kelompok dan memberikan pengalaman langsung".7

Pada dasarnya seni pertunjukan Islam atau pertunjukan wayang kulit adalah bagian atau merupakan budaya kegemaran masyarakat Jawa, pada khususnya di Jawa Timur yang dikenal dengan pertunjukkan wayang kulit, terlepas dari esensi yang akan disampaikan dalam pertunjukkan ala Wali Songo di Jawa Timur yang mendapat respon luar biasa dari masyarakat luas disamping karena menjadi pertunjukkan yang paling digemari, dari sinilah akulturasi budaya kemudian menjadi magnet atau daya tarik luar biasa sehingga persebaran agama Islam tidak memerlukan kekerasan atau perang.

Pertunjukkan wayang yang dibawakan Wali Songo dalam hal esensi yang disampaikan dalam cerita tentu disisipkan unsur-unsur moral keislaman. Dalam lakon Bima Suci misalnya, Bima sebagai tokoh sentralnya diceritakan menyakini adanya Tuhan Yang Maha Esa. Tuhan Yang Esa itulah yang menciptakan dunia dan segala isinya. Tak berhenti di situ, dengan keyakinannya itu Bima mengajarkannya kepada saudaranya, Janaka. Lakon ini juga berisi ajaran-ajaran tentang menuntut ilmu, bersikap sabar, berlaku adil, dan bertatakrama dengan sesama manusia.

h. 62 .

${ }^{7}$ Edi Sedyawati, Pertumbuhan Seni Pertunjukan.(Jakarta: Sinar Harapan, 1981), 
Nur Rahmayani, Fatmawati \& Mohammad Nur Ahsan, Seni Sebagai...

Peran Wali Songo menjadi sangat penting dalam penyebaran agama Islam di Jawa Timur dengan akulturasi budaya yang telah di kembangkan oleh para wali di samping menggunakan wayang sebagai media dakwahnya, para wali juga melakukan dakwahnya melalui berbagai bentuk akulturasi budaya lainnya contohnya melalui penciptaan tembang-tembang keislaman berbahasa Jawa, gamelan, dan lakon islami. Setelah penduduk tertarik, mereka diajak membaca syahadat, diajari wudhu, shalat, dan sebagainya.

Dalam pertunjukan wayang selalu memberikan muatan-muatan ajaran agama yang disampaikan oleh dalang. Ketika sang dalang mulai membawakan cerita dalam pementasan sesungguhnya proses transformasi itu sudah dimulai. Ini seperti halnya proses transformasi yang ada di sekolahan artinya seorang peserta didik tidak akan mengerti dan memahami sepenuhnya apa yang disampaikan seorang guru (dalang) kalau pada prakteknya peserta didik kurang memperhatikan apa yang disampaikan oleh seorang guru.

Pekerjaan seorang dalang yang paling berat karena dia harus berfikir bagaimana pementasannya bisa menarik simpati penonton, karena bagaimanapun transformasi itu sulit diwujudkan kalau penonton tidak memperhatikan dan mendengarkan isi cerita. Musik gamelan, lagulagu yang dibawakan sinden, dan kemampuan dalang dalam menarik wayang adalah kesatuan kreatif yang menjadi syarat utama di dalam mentransformasikan nilai-nilai ajaran Islam. Karena dengan pementasan yang baik dan penonton yang tertib, proses transformasi nilai-nilai ajaran Islam dalam praktek pementasan wayang akan lebih mudah diterima oleh masyarakat. ${ }^{8}$

${ }^{8}$ Ibid., h. 63. 


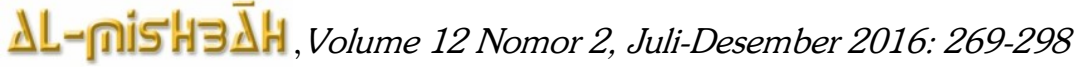

Maka jelaslah bahwa seni pertunjukan Islam merupakan proses Islamisasi dengan menggunakan akulturasi budaya setempat yang berkembang pada saat itu sehingga mampu menarik animo masyarakat luas untuk berbondong-bondong memeluk agama Islam.

Dari penjelasan di atas dapat diketahui bahwa seni merupakan hasil cipta yang mengandung nilai-nilai estetis namun tidak melepaskan nilainilai etika, dalam hal ini seni lebih mengarahkan pada keindahan dalam batas-batas tertentu yang mempengaruhinya, agama adalah yang paling dominan mempengaruhi setiap keindahan bentuk seni. Macam-macam seni yang dapat dinikmati adalah seni tari, seni lukis seni pertunjukan yang merupakan hasil cipta manusia. Seni diharapkan mampu berbicara dengan para penikmatnya sehingga apa yang menjadi maksud dalam sebuah seni dapat dengan mudah diterima.

Seni pertunjukan adalah penggabungan antara seni suara, musik dan tari, keindahan yang diberikan pada penikmatnya lebih mengarahkan pada apa yang ditampilkannya akan membawa dampak atau setidaknya mempengaruhi sebagian atau semua penonton. Maka tidak heran dalam setiap pementasan seni pertunjukan akan memerlukan banyak media yang harus disediakan.

Seni pertunjukan Islam adalah sebuah bentuk seni pertunjukan yang telah berinteraksi dengan agama, artinya dalam hal ini wayang kulit sebagai seni pertunjukan, jadi apa yang terkandung dalam setiap pementasan terdapat unsur keIslaman. Dimana sisi estetis yang di tampilkan mengarah pada nilai-nilai Islam sehingga dalam setiap pagelaran seni pertunjukan yang dipertontonkan mengandung pesanpesan Islam. 
Nur Rahmayani, Fatmawati \& Mohammad Nur Ahsan, Seni Sebagai...

\section{Kajian Tentang Dakwah}

Dakwah merupakan suatu kegiatan ajakan, baik dalam bentuk lisan, tulisan, tingkah laku dan sebagainya yang dilakukan secara sadar dan berencana dalam usaha mempengaruhi orang lain baik secara individu maupun secara kelompok, agar timbul dalam dirinya suatu pengertian, kesadaran, sikap penghayatan serta pengalaman terhadap ajaran agama sebagai pesan yang disampaikan kepadanya tanpa adanya unsur-unsur paksaan.

Secara bahasa, dakwah berasal dari kata “da'a yad'u da'watan yang berarti mengajak, memanggil atau menyeruh". ${ }^{9}$ Namun, secara terminologis ada banyak definisi dakwah yang dikemukakan oleh para ahli. Amrullah Ahmad mendefinisikan "Dakwah sebagai upaya mengajak manusia agar menempuh jalan yang benar yaitu jalan Allah secara menyeluruh baik dengan lisan, tulisan maupun perbuatan sebagai ikhtiar muslim mewujudkan cita-cita Islam menjadi kenyataan kehidupan pribadi dan ummah". ${ }^{10}$

Secara istilah dakwah, seringkali didefinisikan sebagai upaya menyampaikan ajaran Islam kepada manusia, baik dengan lisan maupun dengan tulisan. ${ }^{11}$ Dakwah adalah kegiatan untuk mengkomunikasikan kebenaran ilahiah (agama Islam) yang diyakininya kepada pihak lain. Komunikasi ajaran itu dilakukan sebagai upaya mempengaruhi orang lain agar mereka bersikap dan bertingkah laku islami.

${ }^{9}$ Muhammad Fuad Abd al-Baqy, al-Mu'jam al-Mufahras li Al fadzh Alquran alKarim, (Beirut: Dar al-Fikr, TT), h. 257.

${ }^{10}$ Amrullah Ahmad, Dakwah Islam Sebagai Ilmu: Sebuah Kajian Epistemologi dan Dakwah Islam dan Perubahan Sosial, (Yogyakarta: Primadduta, 1993), h. 2.

${ }^{11}$ Endang S. Anshari, Pokok-Pokok Pikiran Tentang Islam, (Jakarta: Interprises, 1976), h. 87. 


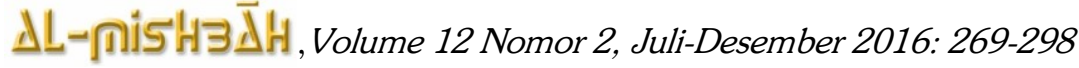

Sementara itu, komunikasi adalah aktivitas pengiriman dan penerimaan pesan yang dilakukan oleh seseorang atau lebih, dan berlangsung dalam sebuah konteks, serta mengharapkan adanya efek. Komunikasi juga merupakan suatu transaksi, proses simbolik yang memungkinkan setiap individu berhubungan satu sama lain dan saling mengatur lingkungannya. Ada beberapa kemungkinan yang bisa dilakukan dengan komunikasi, seperti memantapkan hubungan kemanusiaan, memperteguh sikap dan perilaku orang lain, maupun mengubah sikap dan perilaku orang lain.

Dengan demikian jelas bahwa jika dilihat dari segi proses, dakwah tiada lain adalah komunikasi ajaran Islam, dimana dai menyampaikan pesan ajaran Islam melalui lambang-lambang kepada mad'u dan mad'u menerima pesan itu, mengolahnya dan kemudian meresponnya. Dalam prosesnya terjadi transmisi pesan oleh dai dan interpretasi tersebut tentunya mengharapkan terjadinya efek berupa perubahan kepercayaan, sikap dan tingkah laku mad'u ke arah yang lebih baik, lebih Islami.

Oleh Karena itu, sebagaimana proses komunikasi yang efektif, dalam proses dakwah pun, seorang dai juga harus senantiasa memperhatikan faktor lain yang yang mempengaruhi proses penerimaan pesan.

Sebagai suatu istilah, dakwah memiliki makna sebagai konsep Islam yang mengandung pengertian menyeru kepada hal yang positif, yaitu positif menurut nilai dan norma agama Islam. Ada berbagai macam rumusan mengenai konsep dakwah. Syeh Ali Mahfudz misalnya, mendefinisikan dakwah sebagai usaha memotivisir orang-orang agar tetap menjalankan kebajikan dan memerintahkan mereka untuk berbuat ma'ruf 
Nur Rahmayani, Fatmawati \& Mohammad Nur Ahsan, Seni Sebagai...

serta melarang mereka berbuat mungkar, agar mereka memperoleh kebahagiaan di dunia akhirat. ${ }^{12}$

Dalam makna ini dakwah dipahami sebagai segala upaya yang bertujuan untuk merubah kondisi negatif ke kondisi yang positif untuk memperbaharui dalam makna meningkatkan kondisi yang positif ke kondisi yang lebih positif lagi. Dengan demikian dakwah pada dasarnya adalah bersifat taghyir (pengubah) dari realitas sosial yang tidak ilahiyah menjadi berkondisi atau berwatak ilahiyah.

Agama Islam, pada dasarnya mengajarkan dan mengajak masyarakat untuk meraih kebahagiaan dunia dan akhirat sekaligus sebagaimana tercantum dalam Alquran Surah Al-Baqarah (2) ayat 201;

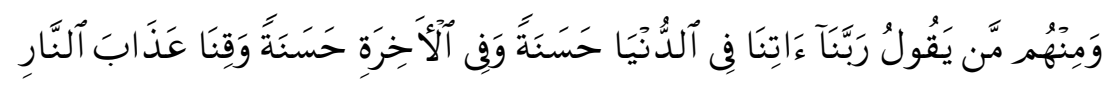

Terjemahnya:

"Dan di antara mereka ada orang yang berdoa: "Ya Tuhan Kami, berilah Kami kebaikan di dunia dan kebaikan di akhirat dan peliharalah Kami dari siksa neraka". ${ }^{13}$

Dengan ruang lingkup dakwah seperti itu, da'i diharapkan memiliki fungsi ganda, yakni melakukan aktivitas penyebaran materi keagamaan dan melakukan pendampingan masyarakat untuk isu-isu korupsi, lingkungan hidup, penggusuran, hak-hak perempuan, konflik antar agama, dan problem kemanusiaan lainnya.

${ }^{12}$ M. Mansyur Amin, Metode Dakwah Islam dan Beberapa Keputusan Pemerintah tentang Aktivitas Keagamaan, (Yogyakarta: Sumbangsih, 1980), h. 15.

${ }^{13}$ Depag RI, Alquran dan Terjemahnya, (Bandung: Mutiara Salib, 2010), h. 59. 
4. Peranan Seni Sebagai Media Dakwah

Dalam Islam dakwah merupakan panggilan kewajiban yang tidak ditentukan oleh struktur sosial, jabatan atau perbedaan warna kulit melainkan bagi seluruh manusia yang mengaku dirinya muslim. Kewajiban berdakwah juga harus disesuaikan dengan kemampuan dan keahlian masing-masing orang (subyek), artinya setiap orang tidak harus melakukan kegiatan dakwah seperti layaknya seorang penceramah atau mubaligh, tetapi berdasarkan kemampuan dan keahlian masing-masing. Seorang seniman bisa berdakwah melalui karya seninya.

Islam adalah agama universal yang mengajarkan banyak hal tentang segala sesuatu, baik dalam perspektif seni budaya, politik, pertahanan sosial dan masih banyak lainnya. Sebagai agama yang mencakup seluruh aspek kehidupan manusia, Islam mampu menjadi pedoman bagi kehidupan umat.Dalam tatanan proposional Islam mampu memberikan kontribusi positif terhadap perkembangan syiar Islam. Pada masa kehidupan Nabi Muhammad saw, media yang paling banyak digunakan adalah media audiatif, yakni menyampaikan dakwah dengan lisan. Namun tidak boleh dilupakan bahwa sikap dan perilaku Nabi juga merupakan media dakwah secara visual yaitu dapat dilihat dan ditiru oleh mitra dakwah. Sejarah dakwah kemudian mencatat bukan hanya perkembangan materi dan objek dakwah, melainkan juga mencari mediamedia dakwah yang efektif. Berupa media visual, audiatif, audio visual, buku , koran, radio, televisi, drama dan sebagainya. Termasuk juga internet, film dan lagu.

Islam sebagai agama dakwah yang universal mewajibkan umatnya untuk melakukan internalisasi, difusi, transformasi dan aktualisasi syiar Islam, karena keuniversalannya itulah Islam mampu menempatkan posisi 
Nur Rahmayani, Fatmawati \& Mohammad Nur Ahsan, Seni Sebagai...

strategis yang mampu menjawab problematika yang muncul di tengah masyarakat modern. Untuk itu suatu kewajiban bagi para dai untuk mengfungsikan media dakwah secara efektif, sehingga dapat menggarahkan umat untuk menguasai teknologi informasi dan komunikasi bagi kepentingan ummah. Dengan begitu maka Islam mampu melaksanakan program dakwah yang antisipasif dan solutif terhadap kompleksitas umat dalam menerima aneka ragam informasi. ${ }^{14}$

Melihat perkembangan dakwah Islamiyah, saat ini banyak ditemukan media berdakwah dengan menggunakan syair lagu. Pada dasarnya media merupakan cara atau alat yang digunakan untuk menyampaikan materi dakwah kepada audiens. Untuk menyampaikan ajaran Islam dapat menggunakan berbagai wasilah (media). Hamzah Ya'qup membagi wasilah menjadi lima macam, yaitu "lisan, tulisan, lukisan, audiovisual dan akhlak". ${ }^{15}$

Begitu juga syair lagu dapat difungsikan sebagai filter bagi masyarakat, yakni dengan memanfaatkan media lagu, maka penyajian informasi-informasi keagamaan (pesan dakwah) dapat disisipkan di dalamnya. Hal ini mampu menjadikan syair lagu lebih bermanfaat dibanding dengan tujuan semula yang hanya merupakan produk dari hasil karya seni seseorang. Oleh Karena itu bagi penyelenggara dakwah pemanfaatan media seperti ini dapatlah kiranya dijadikan sebagai alat untuk menyampaikan misi-misi dakwah Islamiyah.

Menyadari arti penting penggunaan media tersebut, sejak zaman dahulu para dai telah mamanfaatkannya untuk kepentingan dakwah. Kita 1986), h. 12 .

${ }^{14}$ Onong Uchyana Effendy, Komunikasi Dakwah, (Bandung:Remaja Rosdakarya,

${ }^{15}$ M.Munir, Wahyu Ilaihi, Manajemen Dakwah, (Jakarta: Kencana 2006), h. 32. 


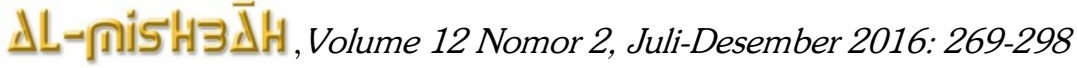

bisa menengok kembali dengan apa yang telah dilakukan oleh Walisongo dalam menjalankan syi'arnya. Mereka melihat bahwa budaya dapat dipakai sebagai sarana untuk mengembangkan dakwah. Oleh karena itu tidak mengherankan pada waktu itu produk budaya semisal wayang ataupun gamelan dimanfaatkan di dalam dakwah. Dalam masa yang lebih maju, Media dakwah sudah semakin berkembang, dakwah sudah tidak lagi dikembangkan hanya sebatas menggunakan media tradisional akan tetapi sudah mulai dikembangkan melalui pemanfaatan mediamedia lain baik melalui lembaga-lembaga formal maupun informal, selain itu pemanfaatan media massa cetak maupun media elektronik ataupun berbagai varian media.

Dalam konteks dakwah Islamiyah di Indonesia, syair-syair lagu yang digunakan sebagai media dakwah merupakan fenomena yang sudah berlangsung lama. Kalau melihat sejarah, sesungguhnya upayaupaya menyampaikan ajaran Islam melalui media seni sudah memiliki umur yang relatif tua. Sunan Kalijaga dan Sunan Bonang misalnya, adalah dua dari sekian banyak tokoh penyebar Islam yang menjadikan musik sebagai media dakwah.

Sunan Kalijaga abad XXI, yakni Emha Ainun Nadjib, juga melakukan hal yang sama melalui musikalisasi kelompok musik Kiai Kanjeng. Ia sanggup mengubah gamelan yang bersal dari tradisi Jawa tersebut menjadi sarana pengungkapan dan penyampaian pesan-pesan dakwah kepada masyarakat. ${ }^{16}$ Musik Kiai Kanjeng dan puisi Ema Ainun Nadjib tidak memfokuskan perhatiannya kepada musik dan puisi itu sendiri. Hal ini karena musik dan puisi bukan pusat kehidupan manusia,

\footnotetext{
${ }^{16}$ Asep Muhyiddin dan Ahmad Safi'i, Metode Pengembangan Dakwah. (Bandung: Pustaka Setia, 2002), h. 212.
} 
Nur Rahmayani, Fatmawati \& Mohammad Nur Ahsan, Seni Sebagai...

melainkan fasilitas estetika akal kebudayaan masyarakat. Musik dan puisi mempermudah komunikasi, memperindah pergaulan, memperdalam cinta kasih.

Sekarang sudah mulai berkembang kembali dengan yang lebih bervarian seperti halnya Rhoma Irama dengan Soneta Groupnya yang diproklamirkan The Sound of Muslim, Sebagai sebuah ikrar untuk menjadikan musik pada umumnya, khususnya dangdut yang banyak digandrungi semua kalangan masyarakat, disamping sebagai sarana hiburan juga dijadikan media dakwah. Misi dakwah Soneta Group terlihat dalam lirik dan syair-syairnya yang kadang-kadang secara vulgar mengajak pada sebuah kesadaran sebagai pesan moral dan ungkapan nurani yang bertanggung jawab.

Sementara itu, dalam nuansa musik yang lain, Ebit G. Ade, Syam Bimbo, Raihan, dan banyak lagi yang lainnya, yang menampilkan warna musik sebagai sarana perenungan, teguran, dan ajakan seperti Opick, yang menyisir syairnya dengan nuansa pop religi, dan bahkan artis-artis lainnya seperti Ungu, dengan lagu Sujudku, Gigi, Dewa, Group band Radja ndengan lagu Lailatul Qadarnya, Jefri Al-Bukhari dengan Syalawat Nariyah. Dan saat ini yang lagi digandrungi adalah lagunya Maherzain dengan alunan syair yang indah sehingga memudahkan pesan dakwah tersampaikan dengan baik tanpa mengurangi makna pesan dakwah sedikit pun karena untuk melaksanakan dakwah Islam diperlukan adanya strategi dakwah yang efektif. Dan peneliti mengira bahwa syair yang bernuansa keagamaan, seperti syair lagu bisa menjadi media dakwah yang efektif untuk berkembangnya syiar Islam.

Dalam perkembangan sejarah kaum muslimin, persinggungan antara dakwah dengan berbagai permasalahan tidak dapat dihindarkan. 


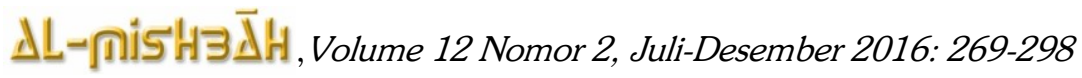

Hal ini sesuai dengan salah satu tujuan dakwah itu sendiri yaitu mengajak umat manusia untuk mengerjakan yang ma'ruf dan menjauhi yang munkar. Seperti yang tercantum dalam Alquran Surah Ali-Imran (3) ayat 104;

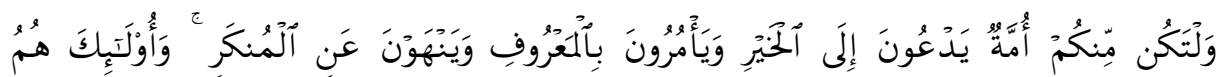

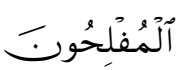

Terjemahnya:

"Dan hendaklah ada di antara kamu segolongan umat yang menyeru kepada kebajikan, menyuruh kepada yang ma'ruf dan mencegah dari yang munkar; merekalah orang-orang yang beruntung". ${ }^{17}$

Bicara tentang dakwah yang kreatif dan inovatif, maka tidak ada salahnya jika membahas kesenian sebagai alternatif lain dalam berdakwah, diantaranya lagu-lagu populer sebagai hiburan atau kesenangan yang digandrungi di seluruh dunia, pria wanita, tua muda sampai anak-anak. Cabang seni yang paling populer adalah seni musik, dimana seni musik sedikit banyak berpengaruh dalam kehidupan manusia, artinya seni musik bisa membuka mata hati manusia untuk melakukan sesuatu hal yang baik, seperti ketika seseorang dalam keadaan yang sulit, patah semangat, dan gelisah, musik dapat menghibur dan membangkitkan semangat.

Sejak awal perkembangan Islam, kesenian memiliki peranan penting dalam dakwah Islamiyah, terutama seni bahasa dan seni suara. Alquran sendiri telah memberi isyarat tentang pentingnya seni di dalam berdakwah. Allah menciptakan Alquran dalam bahasa Arab yang maha

${ }^{17}$ Depag RI, Alquran dan Terjemahnya, (Bandung: Mutiara Salib, 2010), h. 63. 
Nur Rahmayani, Fatmawati \& Mohammad Nur Ahsan, Seni Sebagai...

seni yang luar biasa uslub dan maknanya sehingga tidak dapat ditiru oleh manusia. $^{18}$

Saat ini, musik sudah sangat melekat dengan kehidupan umat muslim. Di mana pun, kapan pun, bahkan dalam kondisi apapun musik tidak terlepas dari mereka. Ada pendapat yang mengatakan bahwa sesungguhnya musik membantu proses belajar. Orang yang belajar dengan diiringi musik, maka ilmu itu akan lebih mudah terpatri di dalam dirinya. Sebagian lagi menganjurkan kepada wanita yang sedang hamil untuk secara rutin memperdengarkan musik klasik pada usia kehamilan tertentu untuk membantu perkembangan pertumbuhan otak si calon bayi.

Bahkan ada yang menyebutkan bahwa orang-orang yang tidak menyukai musik adalah orang yang kasar hatinya. Musik bukan saja dijadikan sebagai sarana hiburan, tetapi juga sebagai media dakwah. Melalui musik, ekspresi kebahagiaan dan pesan-pesan moral keagamaan ditampakkan dan dijabarkan. Sejarah perkembangan dakwah Islam pun penuh dengan percikan seni keindahan, baik dalam wujudnya sebagai hiburan maupun dakwah Islamiyah. Seni musik telah menjadi bagian penting dari keseluruhan sejarah penyebaran ajaran Islam di seluruh dunia. Maka tidaklah mengejutkan jika banyak juga nash-nash yang melegimitasikan keberadaan seni musik sebagai hal yang patut dikembangkan.

Tak pelak jika merebaknya berbagai lagu-lagu Islami menjadi alternatif baru untuk syiar Islam selanjutnya. Membimbing umat menuju kehidupan Islami dengan intelektualitas tinggi dan berwawasan global. Di lingkup agama, lagu-lagu Islami juga menyajikan informasi-informasi

\footnotetext{
${ }^{18}$ A. Hasjmy, Dustur Dakwah Menurut Alquran, (Jakarta: Bulan Bintang, 1974),
} h. 274 
segar tentang masalah-masalah keagamaan. Pesan dakwah yang tersedia pun bervarian, menjawab tentang opini masyarakat berkisar tentang persoalan aktual yang terjadi. Dan salah satu lagu religi yang ikut memberikan pesan dakwah saat ini adalah Maher Zein dengan lagunya "Insya Allah".

Musik sebagai bagian dari seni merupakan alat komunikasi yang cukup efektif, melalui sebuah lagu seseorang dapat menyampaikan sebuah pesan yang sangat mudah diterima dalam hati. Sebuah musik dapat mempengaruhi emosi dan perasaan seseorang yang menikmatinya. Dalam dakwah Islam, seni merupakan bagian dari alat untuk berdakwah yang bisa membawa daya tarik bagi para mad'unya, sehingga tidak membuat suatu kejenuhan akan kajian dakwah yang disampaikan dan terkesan tidak menggurui.

Syair lagu merupakan karya sastra yang disenangi oleh masyarakat. Dalam syair lagu "Insya Allah" mempunyai daya pikat dari segi keindahan bahasa, tema dan susunan kalimat juga rangkaian musiknya sekalipun dengan menggunakan bahasa asing. syair lagu "Insya Allah" mengandung pesan dakwah untuk selalu optimis dan yakin bahwa Tuhan akan selalu bersama hambanya setiap saat, setiap waktu. Unsur seni yang dimiliki oleh sebuah syair lagu akan mampu menggugah jiwa seseorang karena pada dasarnya setiap manusia mempunyai rasa keindahan. Oleh karena itu unsur seni yang ada pada syair atau alunan lagu merupakan faktor yang menentukan keefektifan dalam komunikasi massa melalui lagu.

Hal ini tentunya menjadi poin penting bagi segmen media yang mayoritas beragama Islam, karena informasi telah banyak membantu 
Nur Rahmayani, Fatmawati \& Mohammad Nur Ahsan, Seni Sebagai...

tentang pemahaman keagamaan masyarakat khususnya mereka yang mencintai seni musik dalam mengenal dan menghayati nila-nilai agama.

C. Penerapan bentuk-bentuk seni sebagai media dakwah pada Anak Usia Dini

Seni merupakan unsur yang mengajarkan nilai-nilai estetis dan senantiasa membawa pesan kasih sayang, persaudaraan, dan kebenaran. Pesan tersebut sesuai dengan ajaran Islam yang menganjurkan manusia untuk saling mengenal dan memahami satu sama lain. Relevansi diantara keduanya bukan merupakan suatu kebetulan, melainkan memberikan kepada anak sebuah pemahaman yang sangat bermanfaat bagi terciptanya anak yang berakhlak mulia. Di dalam seni kebenaran dan keadilan senantiasa tampil mengalahkan ketidakbenaran dan ketidakadilan.

Sebagaimana yang kemukakan salah seorang guru di Lembaga PAUD Kabelo Singgah-Singgani bahwa diantara manfaat seni adalah: "mampu membuat anak lebih bijaksana, lebih mencintai hidup, serta lebih mendekatkan anak bukan saja kepada sesama anak tetapi lebih bisa menghargai orang tua" ${ }^{\text {19 }}$

Bentuk kesenian di Lembaga PAUD Kabelo pada dasarnya sama halnya dengan kelompok kesenian yang ada di Lembaga PAUD yang ada di Kota Palu. Bentuk-bentuk penyajian yang ditampilkan ialah: untuk penerimaan lapor anak-anak diperintahkan untuk menghafal surat-surat pendek serta artinya, untuk hari besar Islam dan hari besar Nasional anak-

\footnotetext{
${ }^{19}$ Nur Lailah, Kepala Lembaga PAUD Kabelo Singgah-Singgani, Wawancara, Ruang Kantor, Tanggal 19 Mei 2016.
} 
anak menampilkan kesenian menyanyi dengan memakai alat-alat rebana serta diadakan lomba kaligrafi. ${ }^{20}$

Selain dari kegiatan kesenian, kepala Lembaga PAUD Kableo Singgah-Singgani mengungkapkan bahwa:

"Para guru PAUD biasanya membawa anak-anak PAUD untuk ikut praktek manasik haji setiap musim haji, serta melibatkan anak-anak pada saat ada kegiatan tertentu seperti hari besar Islam (isra miraj) dan hari besar Nasional. Kemudian di dalam setiap kegiatan yang dilakukan oleh lembaga PAUD Kabelo Singgah-Singgani ini, pihak lembaga melibatkan para tokoh agama (ustads), anggota dewan serta orang tua siswa untuk melakukannya secara bersama-sama". ${ }^{21}$

Dari hasil pengalaman peneliti di lapangan dapat dipahami bahwa anak-anak PAUD Kabelo Singgah-Singgani selalu dilibatkan dalam kegiatan-kegiatan hari besar Islam dan perayaan hari Nasional.

Selain dari kegiataa kesenian, ada juga kegiatan-kegiatan menanamkan nilai-nilai Islami terhadap anak, diantaranya:

1. Sebelum masuk pada pelajaran inti, guru menggunakan cara berdakwah tentang akhlak di awal pertemuan.

2. Menyanyikan lagu-lagu qasidah yaitu: tentang shalawat Nabi, mu'zijat wanita kisah-kisah Nabi, mencintai Alquran sejak usia dini, dan

3. Berdoa sebelum pulang kerumah masing-masing. ${ }^{22}$

${ }^{20}$ Farha, Guru PAUD Kabelo Singgah-Singgani, Wawancara, Ruang Guru, Tanggal 23 Mei 2016

${ }^{21}$ Ratni, Guru PAUD, Wawancara, Ruang Guru, Tanggal 30 Mei 2016

${ }^{22}$ Nur Lailah, Kepala Lembaga PAUD Kabelo Singgah-Singgani, Wawancara, Tanggal 06 Mei 2016. 
Nur Rahmayani, Fatmawati \& Mohammad Nur Ahsan, Seni Sebagai...

Dalam penerapan kesenian yang ada di Lembaga PAUD Kabelo Singgah-Singgani. Kesenian ini ditampilkan:

a. Setiap satu kali seminggu pada kegiatan ekstrakurikuler,

b. Tampil di Sekolah Dasar (SD) ketika di undang untuk pementasan, dan

c. Tampil pada saat hari besar Islam dan hari besar Nasional. ${ }^{23}$

Adapun pesan-pesan dakwah dalam penerapan kesenian ini yaitu: ketika anak-anak menyanyikan lagu-lagu yang bernuansa Islam serta lagu-lagu Islami yang menyampaikan pesan dan kesan yang mengajak anak-anak untuk berbuat baik, seperti berbuat baik kepada sesama manusia, menghormati orang tua, tidak bisa berbohong dan selalu melaksanakan perintah Allah dan menjauhi larangannya. ${ }^{24}$

Dalam pelaskanaan seni di Lembaga PAUD Kabelo SinggahSinggani Lembaga PAUD ini menerapkan beberapa seni untuk memberikan pesan-pesan dakwah. Diantaranya seni musik dan seni tari. Sebagaimana yang dikemukakan oleh Ibu Mirna sebagai berikut:

"Fungsi musik dan tari adalah sebagai aspek untuk mempertegas maksud gerak, membentuk suasana tari dan memberi rangsangan estetis pada penari selaras dengan jiwa sesuai dengan maksud karya yang ditampilkan. Music sebagai pengiring tari ada keterkaitan antara keduanya yaitu: musik sebagai pengiring tari, musik sebagai pengikat tari, dan musik sebagai ilustrasi". ${ }^{25}$

Musik sebagai pengikat tari adalah musik yang dibuat sedemikian rupa sehingga mengikat tarinya. Dalam hal ini tari selalu menyesuaikan

${ }^{23}$ Nur Lailah, Kepala Lembaga PAUD Kabelo Singgah-Singgani, Wawancara, Tanggal 21 Juni 2016.

${ }^{24}$ Mirna, Guru PAUD, Wawancara, Ruang Guru, Tanggal 21 Juni 2016.

25 Salhawati, Guru PAUD, Wawancara, Ruang Guru pada Tanggal 7Juni 2016. 
dengan bentuk atau pola musiknya. Pada umumnya kategori ini tari menyesuaikan dengan musik yang telah ada terlebih dahulu.

Musik sebagai ilustrasi tari adalah musik tari yang dalam penyajiannya hanya bersifat ilustrasif atau hanya sebagai penopang suasana tari. Musik dengan tari berjalan sendiri-sendiri tanpa ada kaitan dan tidak ada ketergantungan, namun bertemu dalam satu suasana. Kaitannya dengan analisis tari, fungsi musik sebagaimana sudah dijelaskan, dapat digunakan untuk melihat tarian, bagaimana aspek musik tersebut digunakan dalam koreografinya.

Hal senada juga disampaikan oleh Ibu Ratni sebagai berikut: "Musik Islam merupakan bentuk kesenian yang khas. Ia tidak semata-mata seni untuk alat dalam mencapai tujuan tertentu. Sebab dengan berlandaskan takwa, akan lahir musik Islami yang tetap menjamin kebebasan seorang seniman dalam menciptakan sebuah karya musik. Di Kota Palu banyak ragam musik Islami, baik dilihat dari bentuk maupun isinya, maka sudah sewajarnya bahwa musik Islami adalah musik yang bertemakan kelslaman, yang tidak hanya mempunyai struktur musik yang bersistem nada dan berwarna kearab-araban, tetapi lebih dari itu yaitu mengandung suatu pesanpesan dakwah atau nilai-nilai Islami"” ${ }^{26}$

Di Lembaga PAUD Kabelo Singgah-Singgani, lirik dan syairnya mengandung ajaran-ajaran Islami, petuah, nasehat ataupun ajakan untuk bertakwa kepada Allah swt. mengikuti perintah-perintahnya, serta menghindari larangan-larangannya. Jenis-jenis instrumen seperti salah satunya yaitu qasidah, ciri instrumen Arab seperti rebana, gambus, atau lainnya sengaja ditonjolkan di Lembaga PAUD Kabelo Singgah-Singgani.

Seni sebagai media dakwah secara historis sebenarnya sudah dikenal sejak lama. Pada masa Yunani Kuno, masyarakat sudah

${ }^{26}$ Ratni, Guru PAUD, Wawancara, Ruang Guru, Tanggal 29 Juni 2016 
Nur Rahmayani, Fatmawati \& Mohammad Nur Ahsan, Seni Sebagai...

meletakkan seni sebagai bagian dari rutinitas keagamaan. Bentuk pemujaan kepada para dewa misalnya dilakukan dengan model tarian dan nyayian. Bentuk-bentuk seperti itu ternyata sudah berlangsung dan berkembangan pada agama-agama lain seperti Budha, Hindu, dan Kristen. Agama Hindu dan Kristen, dapat disebutkan bahwa antara seni dan prosesi ritual keagamaan merupakan bagian yang tidak terpisahkan. Setiap prosesi keagamaan selalu diiringi musik, nyanyi, dan tari. Bahkan lukisan naturalistik mengenai Kristus dalam agama Kristen dikategorikan sebagai seni keagamaan. Hal ini dapat dilihat pada masyarakat Bali yang mayoritas penduduknya memeluk agama Hindu, mereka melakukan pemujaan atau sembahyang dan berbagai ritual adat yang di dalamnya terdapat unsur seni yang tidak dapat dipisahkan.

Dalam penerapan seni di Lembaga PAUD Kabelo SinggahSinggani, tentunya tidak lepas dari kendala atau hambatan. Hambatan tersebut diantaranya:

1. Kurangnya perhatian dari pemerintah dalam pengadaan alat-alat kesenian,

2. Malasnya guru dalam mengajar kesenian,

3. Gaji yang tidak mencukupi,

4. Sarana dan prasarana yang sangat minim khususnya dibidang kesenian.

Sedangkan solusi pemecahannya:

1. Membuat sesuatu yang dapat menghasilkan uang untuk mencukupi kebutuhan guru, sarana dan prasarana. Seperti membuat asbak dari tanah liat,

2. Mampu berkreasi sehingga mewujudkan generasi yang terampil seperti: membuat bingkai dari kardus. 


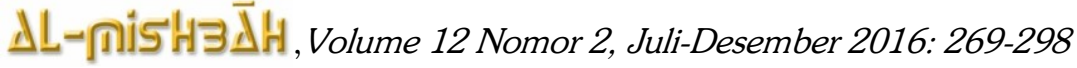

\section{Penutup}

\section{Kesimpulan}

Berdasarkan hasil penlitian yang telah peneliti paparkan pada bab sebelumnya, maka dapat diambil kesimpulan bahwa: Dengan ini, penulis mengajukan beberapa saran yang penulis harapkan akan mampu memberikan masukan bagi pihak terkait, diantaranya:

a. Mengembangkan dakwah di lingkungan Lembaga Pendidikan Anak Usia Dini (PAUD) khususnnya Lembaga PAUD Kabelo yaitu menerapkan kesenian yang sesuai dengan bakat dan minat anakanak, apalagi untuk anak-anak di usia dini. Maka dari itu untuk lembaga PAUD lebih menekankan berbagai media kesenian agar anak bisa memiliki perkembangan.

b. Kesenian yang terdapat di Lembaga PAUD Kabelo SinggahSinggani tumbuh dan berkembang di lingkungan pendidikan anak usia dini (PAUD) adalah kesenian menyanyikan lagu-lagu qasidah, kaligrafi dan tarian daerah. Karena tiga kesenian inilah yang diterapkan di Lembaga PAUD Kabelo Singgah-Singgani selain itu anak-anak dan orang tua siswa sangat menyukai dan mendukung adanya kesenian tersebut. Kesenian yang memfasilitasi lembaga PAUD Kabelo Singgah-Singgani berupa, leptop, microfon dan salon, Rebana. kring-kring besi (renjo), gitar.

c. Adapun pesan-pesan dakwah dalam penerapan kesenian ini yaitu: ketika anak-anak menyanyikan lagu-lagu yang bernuansa Islam serta lagu-lagu Islami yang menyampaikan pesan dan kesan yang mengajak anak-anak untuk berbuat baik, seperti berbuat baik kepada sesama manusia, menghormati orang tua, tidak bisa 
Nur Rahmayani, Fatmawati \& Mohammad Nur Ahsan, Seni Sebagai...

berbohong dan selalu melaksanakan perintah Allah dan menjauhi larangannya.

\section{Implikasi Penelitian}

Berdasarkan hasil temuan peneliti, maka penulis memberikan beberapa saran. Berdasarkan kesimpulan di atas, saran yang dikemukakan yaitu agar kesenian dapat lebih diterima masyarakat maka:

a. Perlu adanya sosialisasi dengan lebih sering dipentaskan. Pembuatan iringan diupayakan untuk dapat dipadukan dengan alat musik modern, baik yang berjenis melodi maupun ritmis. Demikian pula pada hal tata busana agar perlu adanya pengembangan bentuk yang lebih baik lagi, busana yang dikenakan oleh pemain lebih tertutup lagi, memakai kemeja panjang dan celana panjang. Dalam hal musik syair agar lebih dikembangkan lagi, tanpa mengurangi nilai-nilai Islam di dalamnya.

b. Perlu adanya regenerasi pada anggota baik pengiring maupun penari, sehingga mempunya generasi penerusnya. Pemerintah Daerah khususnya Dinas Pendidikan dan Kebudayaan agar lebih meningkatkan pembinaan dan mensosialisasikan dengan mengadakan lomba/festival kesenian tradisional khususnya kesenian kultural.

c. Kepada Kepala Sekolah Lembaga PAUD Kabelo SinggahSinggani, dalam pengembangan kesenian di PAUD, seharusnya pihak Lembaga PAUD melakukan kerjasama dengan para seniman di Kota Palu.

d. Kepada peneliti, hendaknya penelitian ini dapat dijadikan sebagai referensi tambahan dalam penelitian terkait dengan kompetensi 
seniman di bidang kesenian untuk mengembangkan dakwah. Serta hendaknya peneliti selanjutnya memperluas ruang lingkup yang terkait dengan pengelolaan sarana dan prasarana madrasah, sehingga aspek manajerial kepala madrasah yang lainnya dapat tersentuh secara mendalam.

\section{Daftar Pustaka}

Abd al-Baqy, Muhammad Fuad. al-Mu'jam al-Mufahras li Al fadzh Alquran al-Karim. Beirut: Dar al-Fikr, TT

Ahmad, Amrullah. Dakwah Islam Sebagai Ilmu: Sebuah Kajian Epistemologi dan Dakwah Islam dan Perubahan Sosial. Yogyakarta: Primadduta, 1993.

Ali Al-Qahthani bin Said. Dakwah Islam Dakwah Bijak. Jakarta: Gema Insani Press, 1994.

Ali, Muhammad. Penelitian Pendidikan Prosedur dan Strategi. Bandung : Angkasa. 1987.

Amin M. Mansyur. Metode Dakwah Islam dan Beberapa Keputusan Pemerintah tentang Aktivitas Keagamaan. Yogyakarta: Sumbangsih, 1980.

Anas, Ahmad. Paradigma Dakwah Kontemporer. Semarang: Wali Songo Press IAIN Walisongo, 2006.

Anshari, S. Endang. Pokok-Pokok Pikiran Tentang Islam. Jakarta: Interprises, 1976.

Arikunto, Suharsini. Prosedur Penilitian Ilmiah, Suatau Pendekatan Praktek,. Cet. IX. Jakarta: Rineka Cipta, 1993.

Depag RI. Al-Quran dan Terjemahnya. Bandung: Mutiara Salib, 2010.

Edi, Sedyawati. Pertumbuhan Seni Pertunjukan. Jakarta: Sinar Harapan, 1981.

Effendy, Onong Uchyana. Komunikasi Dakwah. Bandung:Remaja Rosdakarya, 1986.

Gazalba, Sidi. Seni dan Agama. Yogyakarta: Lesbuni, 2006. 
Nur Rahmayani, Fatmawati \& Mohammad Nur Ahsan, Seni Sebagai...

Hasjmy. A. Dustur Dakwah Menurut Alquran. Jakarta: Bulan Bintang, 1974.

Kuncoro, "Seni dan Psikologis", dalam www. Arti Seni" diakses pada tanggal 16 Desember 2015

Miles Matthew B. dan A. Michael Huberman. Analisis Data Kualitatif, Buku Tentang Metode-Metode Baru, Cet. I; Jakarta: UI-Press, 1992.

Moleong, Lexy J. Metodologi Penilitian Kualitatif. Bandung: PT. Remaja Rosda Karya, 2001.

Muhyiddin Asep dan Ahmad Safi'i, Metode Pengembangan Dakwah. Bandung: Pustaka Setia. 2002.

Muhyidin Asep dan Agus Ahmad Safei, Metode Pengembangan Dakwah, Bandung: Pustaka Setia. 2002.

Mulyana, Dedi. Penilitian Kualitatif. Bandung: Remaja Rosda Karya, 2003.

Munir. M, Wahyu Ilaihi, Manajemen Dakwah. Jakarta: Kencana 2006.

Prenc. K. M., et.al. Kamus Latin Indonesia. Yogyakarta: Kanisisus, 1969.

Sadiman, Arief S. dkk. Media Pendidikan. Jakarta: Raja Grafika Persada, 1996.

Tasmara, Toto. Komunikasi Dakwah. Jakarta: PT. Gaya Media Pratama, 1997.

William, Raymond, "Art" dalam www. Art, diakses pada tanggal 16 Desember 2015.

Yudhianta, A.A, dkk. Sejarah Budaya Program Pengetahuan Budaya. Klaten: PT Intan Pariwara, 1988.

Yunus, Mahmud, Kamus Arab- Indonesia. Jakarta: Yayasan Penyelengara Penerjemah / Penafsiran Al-Quran.1972.

Yusuf, Yunan. Metode Dakwah Sebuah Pengantar Kajian, Jakarta: Prenada Media, 2003. 